\title{
Internal Standard-based Analytical Method for Tobacco Smoke Vapor Phase Components*
}

\author{
by \\ Fumibiro Omori, Nobukazu Higashi, Masabiro Chida, Yukio Sone, Shizuo Subara \\ Tobacco Science Research Laboratory, \\ Japan Tobacco Inc., \\ Yokohama, Kanagawa, Japan.
}

\section{SUMMARY}

We developed an internal standard-based method to analyze the vapor phase components of mainstream smoke. This method collects vapor phase components from sample cigarettes, which are smoked by a linear automatic smoking machine in a sampling bag. An internal standard gas was introduced to the bag. A 6-port valve with a $2-\mathrm{ml}$ sampling loop was placed between the vapor phase smoke outlet of the smoking machine and the bag to regulate the volume of the internal standard. The mixed gas sample was then introduced, by an automatic injection device developed in-house, to a gas chromatograph (GC) for ten successive analyses. The sample in the bag was analyzed every two hours to assess the time serial changes of vapor phase smoke components as well as of the internal standard. After 18 hours, in the tenth analysis, the amounts of 37 vapor phase components decreased by less than $5 \%$ from those in the first analysis. The repeatability of the sample analysis was assessed and 45 vapor phase components had coefficients of variation of less than $5 \%$. The overall reproducibility of this method including tobacco samples and instruments was also assessed using five other sampling bags and achieved coefficients of variation of less than $6 \%$ for 42 vapor phase components. The advantages of this method include capability to handle 10 tobacco samples in a serial manner, capability to collect both the vapor phase and semivolatile components, and precise, easy and continuous component analyses.
We also present the results of multivariate analyses for the vapor phase and semivolatile components from 59 sample cigarettes. [Beitr. Tabakforsch. Int. 18 (1999) 131- 146]

\section{ZUSAMMENFASSUNG}

Eine Methode mit internem Standard zur Analyse der Gasphasenbestandteile im Cigarettenhauptstromrauch wurde entwickelt. Bei dieser Methode werden Gasphasenbestandteile aus Testcigaretten, die mit einer linearen, automatisierten Rauchmaschine abgeraucht wurden, in einem Probenbeutel gesammelt. Ein internes Standardgas wurde dem Sammelbeutel zugeführt. Ein sechswegiges Ventil mit einer 2-ml Probenschleife wurde zwischen den Gasphasenaustritt der Rauchmaschine und den Auffangbeutel geschaltet, um das Volumen des internen Standards zu regulieren. Die Gasprobenmischung wurde dann mit Hilfe einer automatischen Einspritzvorrichtung, die im Haus entwickelt wurde, einem Gaschromatographen für 10 aufeinanderfolgende Analysen zugeführt. Die Probe in dem Sammelbeutel wurde alle zwei Stunden analysiert, um sowohl zeitliche Veränderungen der Gasphasenbestandteile des Cigarettenhauptstromrauchs als auch Veränderungen des internen Standards zu messen. Nach 18 Stunden, während der zehnten Analyse, waren die Mengen von 37 Gasphasenbestandteilen um weniger als $5 \%$ niedriger als bei der ersten Analyse. Die Wiederholbarkeit der Probenanalyse wurde berechnet und bei 45 Gasphasenbestandteilen waren die Variationskoeffizienten unter $5 \%$. Die Reproduzierbarkeit der 
Gesamtmethode einschließlich der verwendeten Tabakproben und Instrumente wurde ebenfalls bestimmt, indem fünf weitere Auffangbeutel installiert wurden. Hierbei waren die Variationskoeffizienten von 42 Gasphasenbestandteilen niedriger als $6 \%$. Die Vorteile dieser Methode bestehen darin, dass 10 Tabakproben in Serie untersucht werden können, dass sowohl Gasphasenbestandteile als auch semivolatile Komponenten aufgefangen werden können und dass eine präzise, einfache und kontinuierliche Analyse der Bestandteile des Hauptstromrauchs möglich ist.

Die Resultate der multivariaten Analyse von Gasphasenbestandteilen und semivolatilen Bestandteilen von 56 Tabakproben werden ebenfalls beschrieben. [Beitr. Tabakforsch. Int. 18 (1999) 131-146]

\section{RESUME}

Une méthode permettant d'introduire un étalon interne pour doser les composants de la phase gazeuse du courant principale de cigarettes a été développé. Ce système recueille dans un sac d'échantillons les composants de la phase gazeuse de cigarettes d'essais qui sont fumées avec une machine à fumer automatique linéaire. Le sac a été chargé d'un étalon interne. Une valve à six canaux avec une boucle d'échantillons de 2-ml était installée entre l'orifice d'émission de la phase gazeuse sur la machine à fumer et le sac d'échantillonnage à chaque canal pour régler le volume de l'étalon interne. L'échantillon du mélange de gaz a été ajouté dans le système GC à l'aide d'un dispositif d'injection de fabrication ,maison" pour dix analyses consécutives. L'échantillon recueilli dans le sac de gaz a été analysé toutes les deux heures pour déterminer les changements en fonction du temps des composants de la phase gazeuse de la fumée et de l'étalon interne. Après 18 heures, au cours de la dixième analyse, les rendements de 37 composants de la phase gazeuse avaient diminués de moins de $5 \%$ comparée aux résultats obtenus après la première analyse. La réproductibilité globale de cette méthode incluant les échantillons de tabacs et les instruments était également calculée à l'aide de cinq autres sacs d'échantillonnage et le coefficient de variation du système résultant était inférieur à $6 \%$ pour 42 composants de la phase gazeuse. L'avantage de cette méthode comprend la capacité de manoeuvrer 10 échantillons de tabacs consécutivement, la possibilité de recueillir simultanément la phase gazeuse et les composants semi-volatiles et d'effectuer l'analyse en composante d'une manière précise, simple et continue.

Nous présentons également les résultats d'analyses multivariables appliquées aux composants analysés de la phase gazeuse et semi-volatile de 59 échantillons. [Beitr. Tabakforsch. Int. 18 (1999) 131-146]

\section{INTRODUCTION}

Scientists have actively developed a variety of analytical methods to determine the composition of mainstream and sidestream smoke more precisely, efficiently and simply. The composition of cigarette smoke depends on the types of tobacco leaf, cigarette paper and filter as well as the flavoring agents to be added. One report gives an indication of the composition of cigarette mainstream smoke (1). According to the report, gas phase components, mainly atmospheric nitrogen and oxygen, account for over $80 \%$ (weight ratio) of mainstream smoke. The remaining less than $20 \%$ is comprised of vapor phase components of which about $80 \%$ is accounted for by $\mathrm{CO}_{2}$, about $10 \%$ by water, and the rest by hydrocarbons, carbonyls and furanes. Although particulate matter, trapped on the Cambridge filter, accounts for only a few percent of total mainstream smoke, over $90 \%$ of the smoke components so far reported belong to particulate matter. Together with nicotine, the levels of these particulate matter components and their proportion heavily affect the taste and aroma of a particular cigarette whereas vapor phase components contribute to irritation $(2,3)$.

Analyzing both semivolatile and vapor phase components will not only provide basic scientific knowledge, but also have a practical benefit of clarifying the type of substances that consumers take in through direct or indirect smoking of cigarette products. Unlike the analyses of semivolatile components, vapor phase components analyses have failed to provide authentic data due to their poor precision and low efficiency.

More recent methods for vapor phase component analysis are divided into four major types according to their trapping approaches: direct injection $(4,5)$; cryogenic trap (6-12); adsorbent trap (13-16); and the sampling bag method (17). The direct injection method has an advantage of measuring fresh cigarette smoke and minimizing component degradation with time and reactions among components. Because of the limited volume that can be introduced into GC, only one puff of vapor phase components or a part of it may be measured, resulting in a sharp fluctuation in measurements which makes quantitative analysis difficult. The procedure is also complex. Cryogenic trapping has the advantages of easy addition of internal standards to vapor phase components and minimized component degradation with time because it handles them at very low temperatures. Because of these advantages, this method is often used to collect certain vapor phase components. However, the procedure involved is very complex and the method requires that component solubility and volatility 


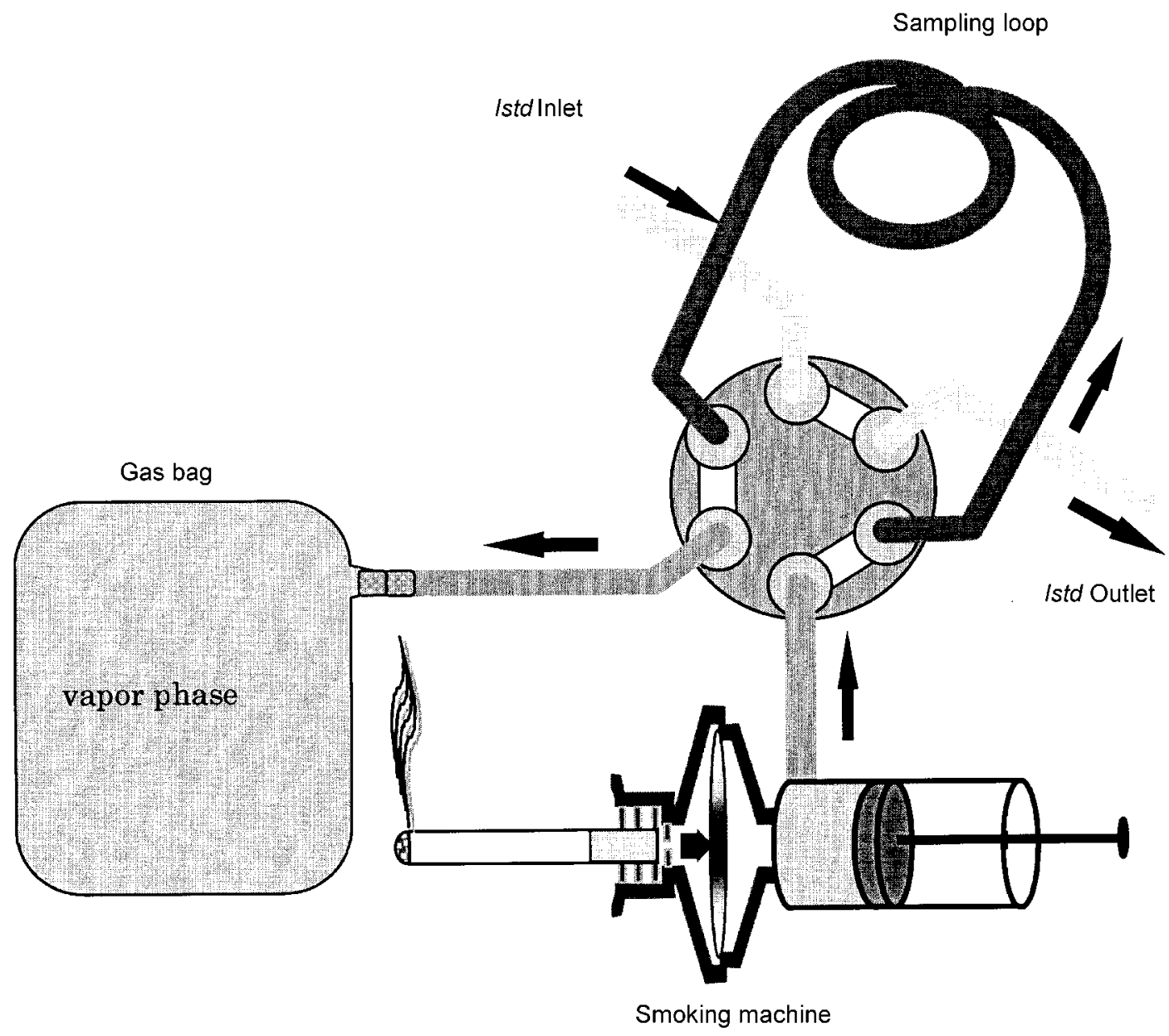

Figure 1.

Collection of mainstream smoke. One of 10 valves is shown.

to be taken into account. Thus, it is not always the best option to analyze all vapor phase components. Absorbent trapping can concentrate vapor phase components present at extremely low concentrations and thus it is widely used to collect air components (18). However, adsorption and desorption by the adsorbent used must be considered for each component, making it unsuitable for collecting all vapor phase components. While the sampling bag method can collect all vapor phase components, the collected components can degrade in the bag at room temperature. Since our study aims to analyze all vapor phase components, the sampling bag method was selected. An internal standard was used for quantitative analysis.

Previously, in the first phase of our study, we reported the automatic injection device we developed for use with GC (19) and, in the second phase, the use of the internal standard to analyze a wider array of vapor phase components (20). In the present report, we describe our analytical method in detail and present more data from the vapor phase component analysis to substantiate its usefulness.

\section{EXPERIMENTAL METHOD}

\section{Cigarette samples}

Commercially available cigarette samples from the Japanese market with $17 \mathrm{mg}$ tar and a filter, were conditioned at $22{ }^{\circ} \mathrm{C}$ and $60 \% \mathrm{RH}$ for over 2 days.

\section{Collection method}

In accordance with the Tobacco Institute of Japan (TIOJ) puffing regimen (21) (puff volume: $35 \mathrm{~mL}$, puff duration: $2 \mathrm{~s}$, puff interval: $60 \mathrm{~s}$ ), three sample cigarettes were smoked on a 20-port automatic linear smoking machine to collect their mainstream smoke components. The mainstream smoke was fractionated using a $26 \mathrm{~mm}$ Cambridge filter. We defined the components that passed the filter as vapor phase components and those that were trapped by the filter as semivolatile and nonvolatile components; however, only the vapor phase and semivolatile fractions were analyzed. The automatic smoking machine was modified to minimize the dead volume between the cylinder and the vapor phase component outlet. 


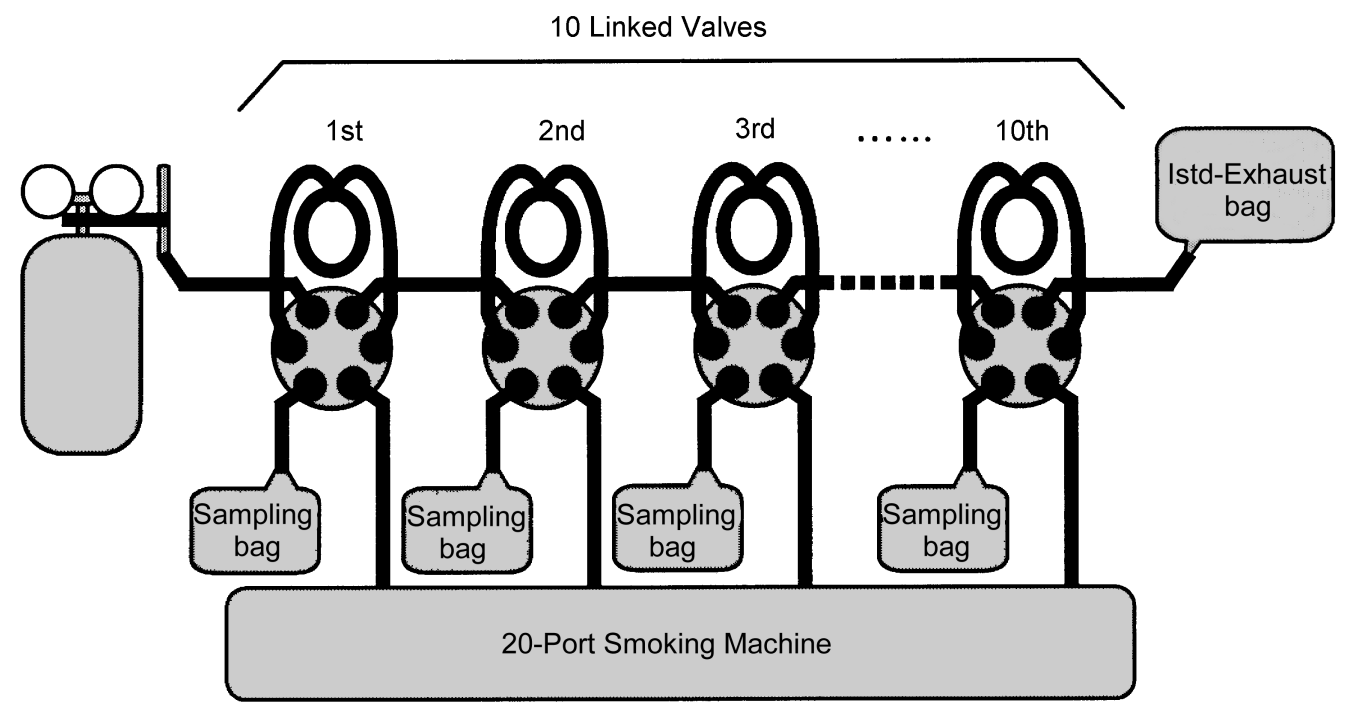

Figure 2.

Linked six-port valves. Step 1: Internal standard gas is fed to 10 sampling loops; step 2: Istd-exhaust bag is fitted to the $10^{\text {th }}$ valve; step 3: internal standard gas is stopped to be fed; step 4: each valve is turned to connect the smoking machine, a sampling loop and a sampling bag; step 5: internal standard gas is introduced into the sampling bag by blank puff; step 6: each valve is turned back to connect the smoking machine and a sampling bag without a sampling loop; step 7: the cigarette is smoked to collect vapor phase and semivolatile components.

\section{Collection of vapor phase components}

A 6-port valve with a $2 \mathrm{~mL}$ sampling loop was placed between the smoking machine and a 4-layer aluminum bag. All the vapor phase components from the first puff to the last puff from three cigarettes were collected in the bag through the valve (Figure 1).

\section{Internal standard gas}

One percent 1,1,1,2-tetrafluoroethane balanced with helium was prepared in a gas cylinder to be used as the internal standard. The flow of the internal standard from the gas cylinder was regulated by a control valve to feed the gas at $100 \mathrm{~mL}$ per minute into the sampling loop on

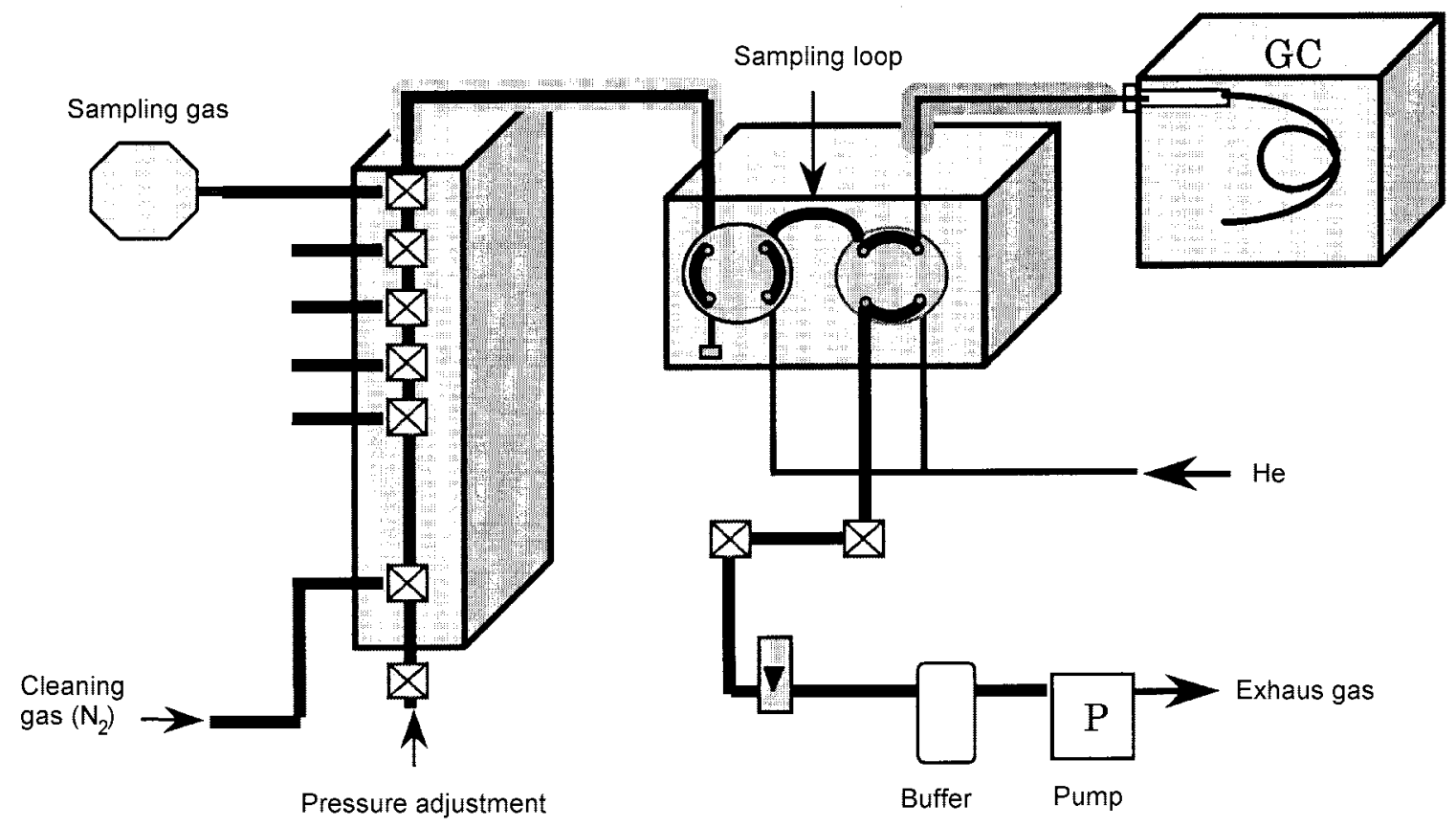

Figure 3.

Vapor phase component analytical system. 
Table 1.

Vapor phase components.

\begin{tabular}{|c|c|c|c|}
\hline Peak & Name & Peak & Name \\
\hline V2 & Methane & V32 & Isoprene \\
\hline V3 & Ethylene \& Acetylene & V35 & unknown \\
\hline V4 & Ethane & V36 & Propionitrile \\
\hline V5 & Propene & V38 & unknown \\
\hline V6 & Propane & V39 & unknown \\
\hline v9 & unknown & V40 & Methylvinylketone \\
\hline V10 & Methylacetylene & V41 & 2-Methylfuran \\
\hline V11 & Methanol & V42 & Diacethyl \\
\hline V12 & Acetaldehyde & V43 & Methylethylketone \\
\hline V14 & Isobutane & V44 & Methylacrylate \\
\hline V16 & 1-Butene & V45 & Isobutyronitrile \\
\hline V17 & 1,3-Butadiene & V46 & Crotonaldehyde \\
\hline V18 & $n$-Butane & V48 & unknown \\
\hline V19 & trans-2-Butene & V50 & Benzene \\
\hline V20 & cis-2-Butene & V51 & Butyronitrile \\
\hline V21 & unknown & V52 & unknown \\
\hline V22 & Acetonitrile & V53 & Dimethylfurane \\
\hline V23 & Acroleine & V54 & unknown \\
\hline V24 & Furan & V55 & unknown \\
\hline V25 & Propionaldehyde & V56 & $n$-Heptane \\
\hline V26 & Acetone & V57 & Toluene \\
\hline V27 & Acryronitrile & V60 & unknown \\
\hline V30 & Methylacetate & V61 & unknown \\
\hline V31 & Cyclopentadiene & & \\
\hline
\end{tabular}

the six-port valve. In order to analyze ten vapor phase component samples at a time, ten six-port valves were connected serially with the internal standard outlet of the first valve connected to the internal standard inlet on the next valve. Once the pressure in each sampling loop of the six-port valves is in equilibrium, then the sampling loop on each six-port valve mechanically holds that pressure. This means that each sampling loop on the sixport valves has the same amount of the internal standard gas (Figure 2). After the gas was fed to ten sampling loops for two minutes, the exhaust bag was fitted to the internal standard outlet of the 10th valve and supplied with gas for one more minute. Thirty seconds after the valve of the gas cylinder was closed, each six-port valve was turned to connect the smoking machine, a sampling loop and a sampling bag. The internal standard gas in the sampling loop was forced into the sampling bag by a blank puff of the smoking machine. This procedure was followed by the collecting of the cigarette smoke, and the mixture of the internal standard and vapor phase components were collected in ten bags in a single step.

\section{Gas chromatographic analysis of vapor phase components}

For simple and stable determination of vapor phase components collected in the sampling bag, our team developed an automatic injection device (19). This injection device (Figure 3) has a sampling loop that dispenses $5 \mathrm{ml}$ of vapor phase components at a time from up to ten sampling bags to be supplied to the GC for 


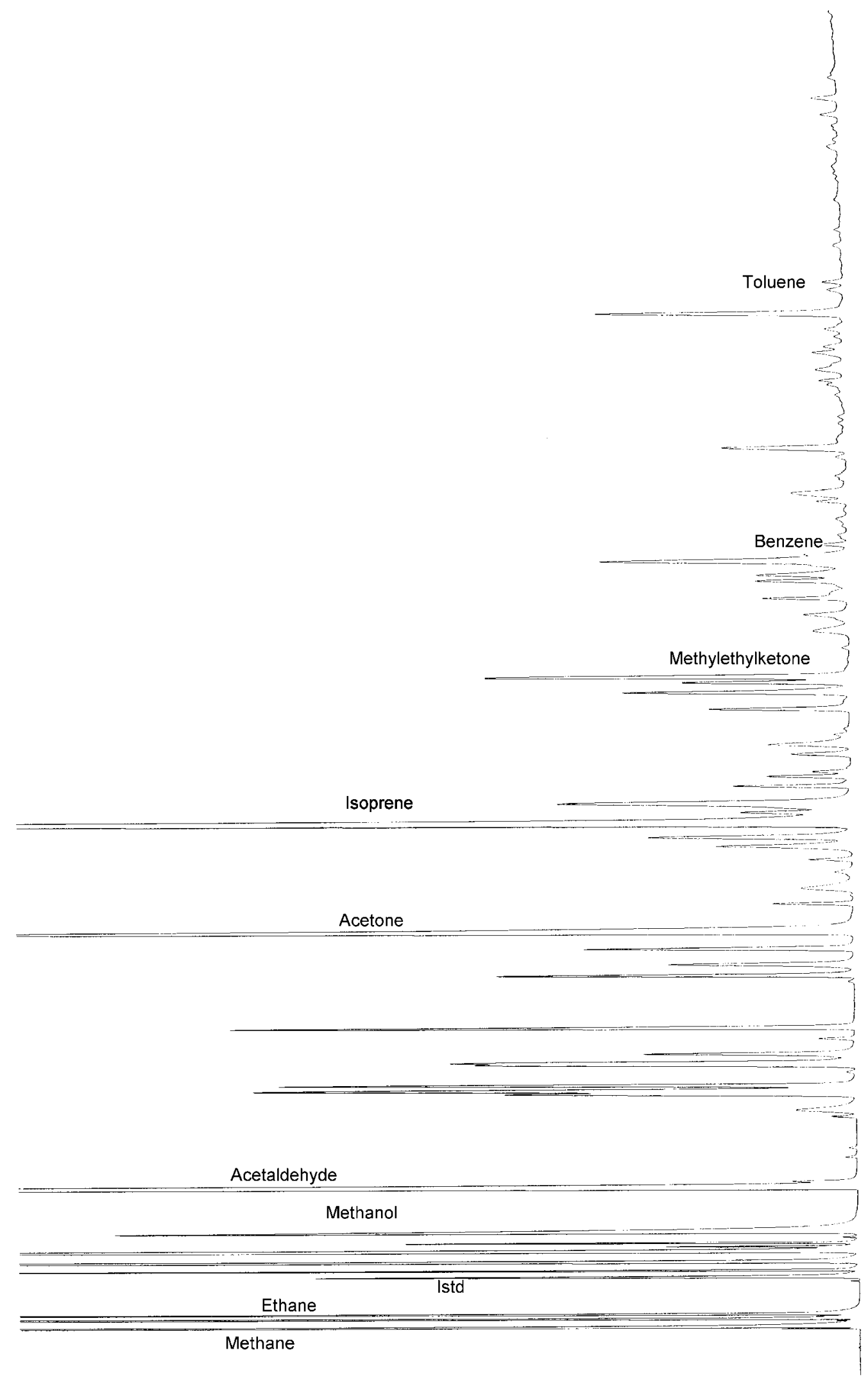

Figure 4.

Chromatogram of vapor phase components.

automatic analysis. A valve switching system changes the sample flow line to direct the sample in the loop to the GC. The sample is carried by He which is controlled by an electronic pressure controller (EPC). A HewlettPackard HP 5890 Series II GC-FID system was used. Vapor phase components were fed, by He carrier gas with 


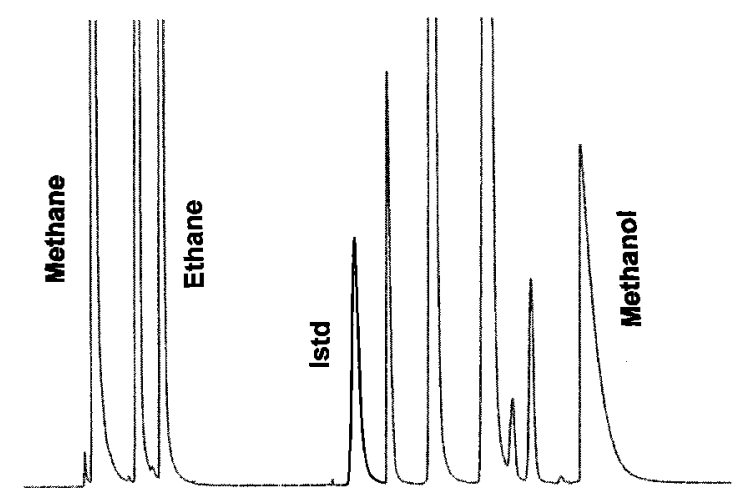

Figure 5 .

Peak of Istd. elevated temperature was held for 10 minutes. The analyzed vapor phase components and their chromatogram are shown in Table 1 and Figures 4 and 5. Each component was identified by GC-MS and its retention time.

\section{Semivolatile components analysis}

The semivolatile components, trapped on the Cambridge filter, were extracted with $0.75 \mathrm{~mL}$ of dichloromethane and methanol (4:1) containing ethyl phenyl acetate (0.45 mg) as an internal standard, followed by GC analysis. A Hewlett-Packard HP 5890 Series II GC-FID system was used. Semivolatile components were fed, by $\mathrm{He}$ carrier gas with a head pressure of 13.9 p.s.i.g. (constant

Table 2.

Semivolatile components.

\begin{tabular}{|c|c|c|c|}
\hline Peak & Name & Peak & Name \\
\hline S2 & 2,3-Butandione & S25 & Solanone \\
\hline S3 & 1-Pentene-3-one & S26 & unknown \\
\hline S4 & Toluene & S27 & Nicotine \\
\hline S5 & $m$-Xylene & S28 & 3-Ethyl-2-hydroxy-cyclopenten-1-one \\
\hline S6 & Cyclopentanone & S29 & Neophytadiene \\
\hline S7 & Pyridine & S30 & Phenol \& o-Cresol \\
\hline S8 & Limonene & S31 & 2-Pyrrolidone \\
\hline S11 & 3-Methylpyridine & S32 & 2,5-Dimethyl-4-hydroxy-3(2H)-furanone \\
\hline S12 & 2-Cyclopentene-1-one & S33 & p-Cresol \\
\hline S13 & 2-Methyl-2-cyclopentene-1-one & S35 & $m$-Cresol \\
\hline $\mathrm{S} 14$ & 3-Ethylpyridine & S37 & 2,3-Dihydro-3,5-dihydroxy-6-methyl-4H-pyran-4-one \\
\hline S15 & Acetic acid & S38 & Glycerol \\
\hline S16 & 3-Vinylpyridine & S39 & 4-Vinylphenol \\
\hline $\mathrm{S} 17$ & 3-Methyl-2-cyclopentene-1-one & S40 & 3-Hydroxypyridine \\
\hline S18 & Pyrrole & S41 & Indole \\
\hline S19 & 2,3-Dimethyl-2-cyclopentene-1-one & S43 & 5-Hydroxymethyl-2-furaldehyde \\
\hline S20 & 5-Methyl-2-furfuran & S47 & Hexadecanoic acid \\
\hline S21 & unknown & S48 & 1,4-Benzenediol \\
\hline S24 & Furfurylalcohol & S49 & Hentriacontane \\
\hline
\end{tabular}

a head pressure of 27.5 p.s.i.g. (constant flow mode), to a PoraPLOT $\mathrm{Q}^{\mathrm{TM}}(25 \mathrm{~mm} \times 0.32 \mathrm{~mm}$ i.d., $10 \mu \mathrm{m}$ film thickness) fused-silica capillary column for separation. The temperature of the injection port was $225^{\circ} \mathrm{C}$ in the split mode (split, 40:1) and that of the detector was $225^{\circ} \mathrm{C}$. The $\mathrm{GC}$ oven was held at $60^{\circ} \mathrm{C}$ for 16 minutes, followed by heating at $2{ }^{\circ} \mathrm{C} / \mathrm{min}$ to $230{ }^{\circ} \mathrm{C}$ and the flow mode), to a DBTM-WAX (30 $\mathrm{mm} \times 0.25 \mathrm{~mm}$ i.d., $0.25 \mu \mathrm{m}$ film thickness) fused-silica capillary column for separation. The temperature for the injection port was $250^{\circ} \mathrm{C}$ in the split mode (split, 22.5:1) and that for the detector was $250^{\circ} \mathrm{C}$. The GC oven was held at $50^{\circ} \mathrm{C}$ for 7 minutes, followed by heating at $2{ }^{\circ} \mathrm{C} / \mathrm{min}$ to $240{ }^{\circ} \mathrm{C}$ 


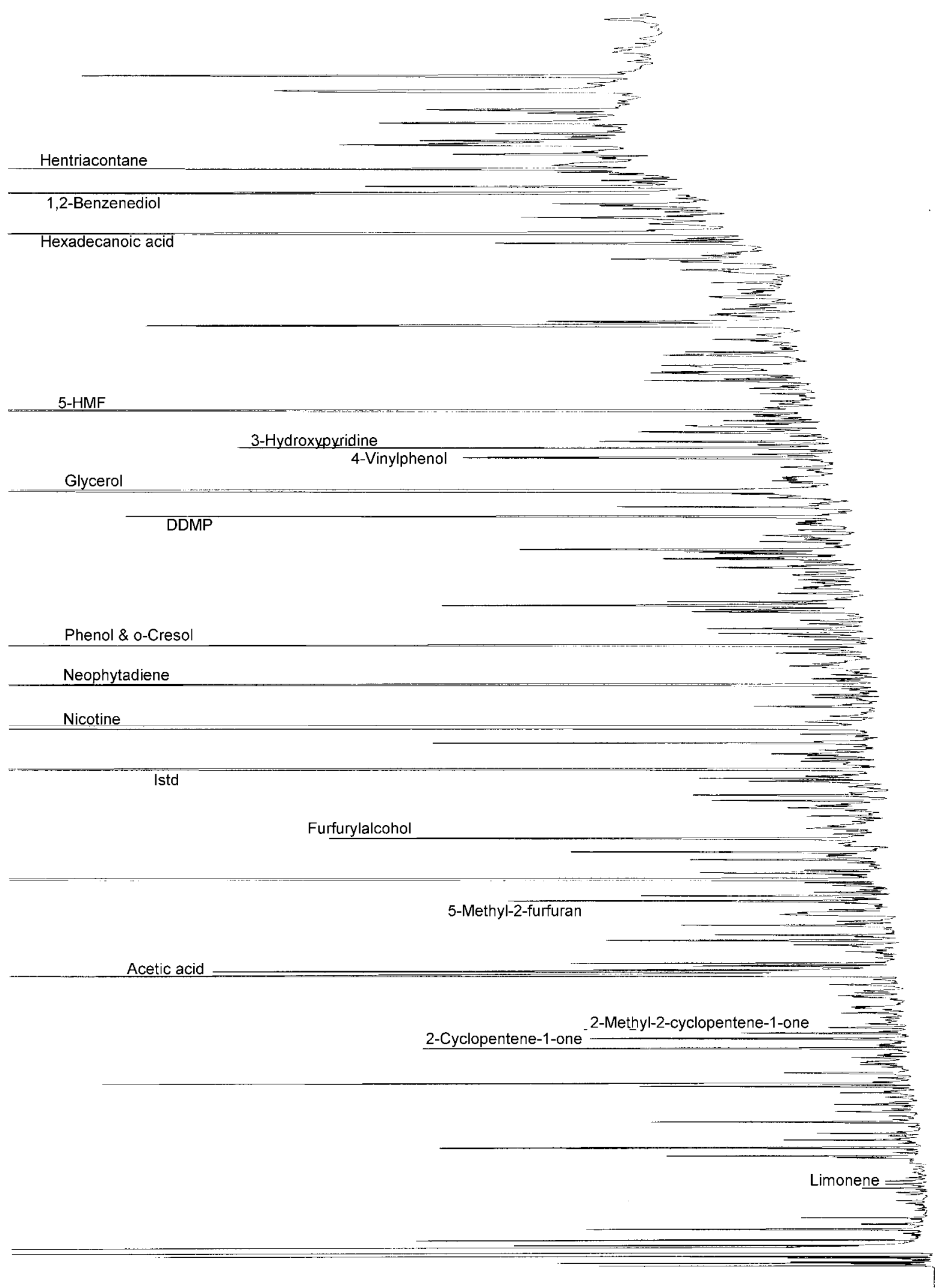

Figure 6.

Chromatogram of semivolatile components.

and the elevated temperature was held for 50 minutes. The analyzed semivolatile components and their chroma- togram are shown in Table 2 and Figure 6. Each component was identified by GC-MS and its retention time. 


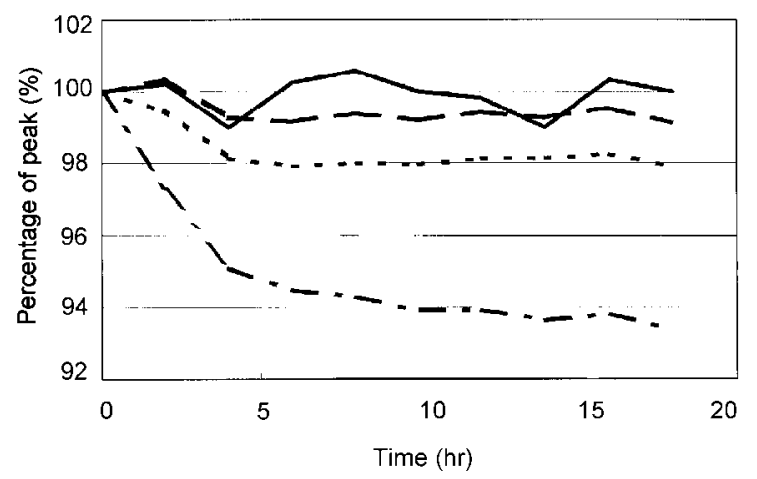

Figure 7.

Time serial changes of vapor phase components. The same sampling bag was analyzed 10 times at twohour intervals. ( --- : Acetone; - : Benzene; - - - : Acrolein; - - - : Acetaldehyde).

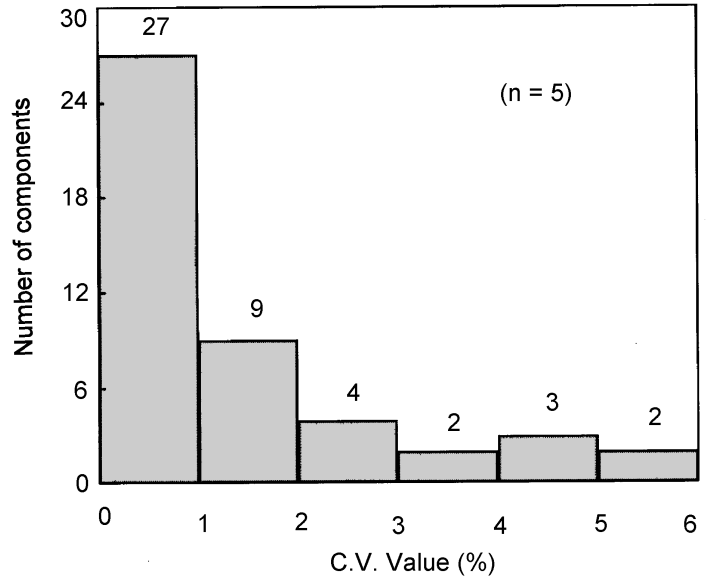

Figure 8.

Repeatability of vapor phase components analysis.

Quantitative analysis of vapor phase components

One percent isobutane, 1-butene, 1,3-butadiene, benzene, toluene, methanol, cis-2-butene and $n$-heptane balanced with helium was prepared in each gas cylinder as the reference gas. Each sample gas was diluted with helium and mixed with $2 \mathrm{ml}$ of the internal standard gas on the automatic smoking machine.

\section{RESULT}

\section{Selection of internal standard}

In order to determine the optimum internal standard, we examined halides, especially fluorides, which are not present in the vapor phase components. Most internal

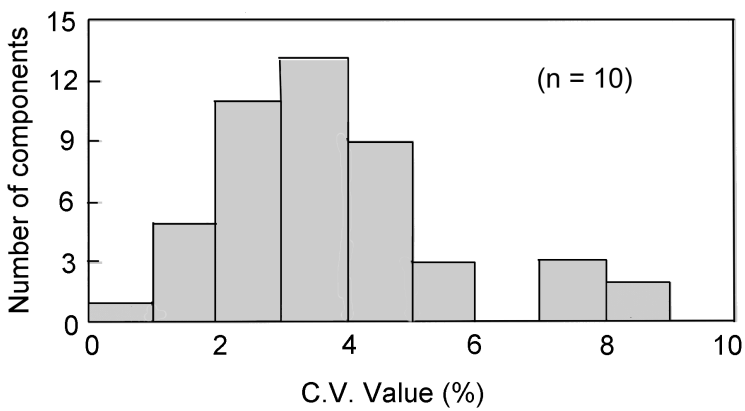

Figure 9.

Reproducibility of vapor phase components analysis.

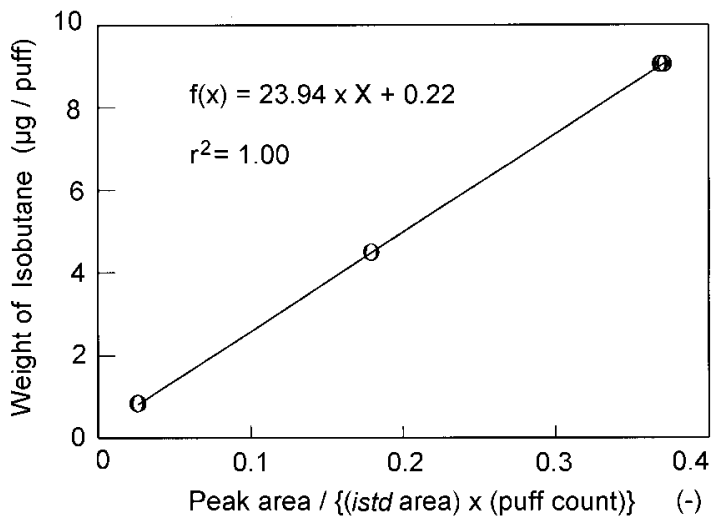

Figure 10.

Example of a calibration curve.

standard candidates other than the controlled ozonedepleting substances overlapped with the collected vapor phase components on the chromatogram. The only substance that separated distinctively from collected vapor phase components was 1,1,1,2-tetrafluoroethane (Figure 5).

Time-serial changes in collected vapor phase components

Our system automatically analyzes 10 samples in a successive manner and it takes approximately 18 hours to complete the serial analysis of all the 10 samples. In order to evaluate the effect of time elapses during the serial analysis on the stability of the vapor phase components collected in the sampling bag, a sample in the same bag was analyzed under the same conditions every 2 hours for 18 hours. During this 18 -hour period, the measured values of 24 out of 47 vapor phase component samples decreased only by less than $1 \%$ and 13 out of 47 decreased by 1-5\%. The time-serial changes of four representative components are shown in Figure 7. When 
Table 3.

Tobacco samples.

\begin{tabular}{l|c|c}
\hline Variety & Origin & $\begin{array}{c}\text { Number of } \\
\text { samples }\end{array}$ \\
\hline Flue-cured & Japan & 8 \\
& USA & 6 \\
Burley & Japan & 8 \\
& USA & 7 \\
Oriental & & 10 \\
\hline Total & & 39 \\
\hline
\end{tabular}

these measurements are presented as the results of repeated analyses of the same samples in the same bag, 45 out of 47 components have a coefficient of variation (CV) of less than $5 \%$. These CV are sufficiently low and thus the series of analyses may be considered to have sufficiently good repeatability (Figure 8).

\section{Reproducibility of vapor phase components analysis}

The precision of our analytical system was also evaluated by repeating the analysis 5 times. The procedures involved smoking the sample cigarettes and analyzing their vapor phase components on GC. Forty-two out of 47 vapor phase components analyzed had a CV of less than $6 \%$ (Figure 9).

\section{Quantitative analysis of vapor phase components}

For isobutane, the linearity of the system response was determined $\left(r^{2}=1\right)$ within the expected range of concentration from the calibration plots of the reference gas (Figure 10). Response linearity was also confirmed for other vapor phase components. Based on these calibration curves, 39 tobacco samples (Table 3) were analyzed and the average quantitative values of different types and origins of tobacco leaves are shown as the average weight of the entire puff in Table 4.

\section{APPLICATION}

The possibilities of classifying cigarettes by tobacco variety, by country of origin and by stalk position based on the vapor phase and semivolatile component data, were evaluated. The data from 59 different tobacco samples (Table 5) were analyzed using principal component analysis (PCA), a kind of multivariate analysis. We already confirmed and reported that the data from the extracts of tobacco leaves were useful to classify the varieties of total tobacco leaves, the counties of origin and the stalk positions of both flue-cured and Burley tobacco samples $(22,23)$.

Table 4.

Average weight of vapor phase components ( $\mu \mathrm{g} / \mathrm{puff})$.

\begin{tabular}{l|c|c|c|c|c}
\hline \multirow{2}{*}{ Components } & \multicolumn{2}{c}{ Flue-cured } & \multicolumn{2}{c|}{ Burley } & Oriental \\
\cline { 2 - 6 } & Japan (SD) & USA (SD) & Japan (SD) & USA (SD) & $(S D)$ \\
\hline Isobutane & $1.35(0.15)$ & $1.53(0.14)$ & $1.33(0.16)$ & $1.69(0.10)$ & $1.59(0.15)$ \\
1-Butene & $5.29(0.20)$ & $6.02(0.49)$ & $5.09(0.43)$ & $5.54(0.37)$ & $5.38(0.40)$ \\
1,3-Butadiene & $4.73(0.40)$ & $5.87(0.73)$ & $4.84(0.53)$ & $3.66(0.93)$ & $4.47(0.40)$ \\
Benzene & $5.84(0.25)$ & $5.77(0.20)$ & $5.65(0.52)$ & $6.29(0.62)$ & $5.53(0.49)$ \\
Toluene & $7.21(0.85)$ & $7.66(0.71)$ & $6.75(1.13)$ & $7.30(0.95)$ & $6.56(0.46)$ \\
Methanol & $15.49(3.62)$ & $39.58(5.37)$ & $27.74(7.53)$ & $14.29(1.05)$ & $15.04(5.44)$ \\
cis-2-Butene & $2.56(0.09)$ & $2.83(0.20)$ & $2.7(0.33)$ & $2.77(0.16)$ & $2.55(0.20)$ \\
$n$-Heptane & $0.60(0.06)$ & $0.71(0.40)$ & $0.82(0.21)$ & $1.10(0.18)$ & $0.59(0.08)$ \\
\hline
\end{tabular}


Table 5.

Tobacco samples.

\begin{tabular}{l|c|c}
\hline Variety & Origin & $\begin{array}{c}\text { Number of } \\
\text { samples }\end{array}$ \\
\hline Flue-cured & Japan & 8 \\
& USA & 6 \\
& Other & 10 \\
Burley & Japan & 8 \\
& USA & 7 \\
& Other & 10 \\
Oriental & & 10 \\
\hline Total & & 59 \\
\hline
\end{tabular}

SPSS Ver. 6 computer software. The factor loadings and the principal component scores, generated by PCA, are shown in Figures 11 and 12. In the chart of the principal component scores, the combination of the first and second principal components successfully identified the variety of total tobacco leaves. However, the plots are not particularly distinctive for counties of origin for both fluecured and Burley tobaccos. From the chart of factor loadings, it is shown that propane (V6), crotonaldehyde (V46), 1-butene (V16) and benzene (V50) contribute most to the first principal components, whereas methyl acetate (V30) and furan (V24) contribute most to the second principal components. Because hydrocarbons, carboxylic acids, esters, ketones and aldehydes were distributed intricately throughout the scattered plots of factor loadings, the relation between tobacco leaves and vapor phase components could not be identified.

Table 6.

PCA of vapor phase components.

\begin{tabular}{l|c|c|c}
\hline \multicolumn{1}{c|}{ Factor } & Eigenvalue & Proportion & Cumulative proportion \\
\hline 1 & 6.59 & 0.412 & 0.412 \\
2 & 4.32 & 0.270 & 0.681 \\
3 & 2.05 & 0.128 & 0.809 \\
4 & 1.07 & 0.067 & 0.876 \\
\hline
\end{tabular}

Table 7.

PCA of semivolatile components.

\begin{tabular}{l|c|c|c}
\hline \multicolumn{1}{c}{ Factor } & Eigenvalue & Proportion & Cumulative proportion \\
\hline 1 & 5.15 & 0.396 & 0.396 \\
2 & 2.80 & 0.215 & 0.612 \\
3 & 1.55 & 0.119 & 0.731 \\
4 & 1.23 & 0.095 & 0.825 \\
\hline
\end{tabular}

Principal component analysis using vapor phase components data

The data on 41 vapor phase components were analyzed using PCA (Table 6). The PCA was performed using
Principal component analysis using semivolatile component data

The data on 38 semivolatile components were analyzed using PCA (Table 7, Figures 13 and 14). In the chart of 


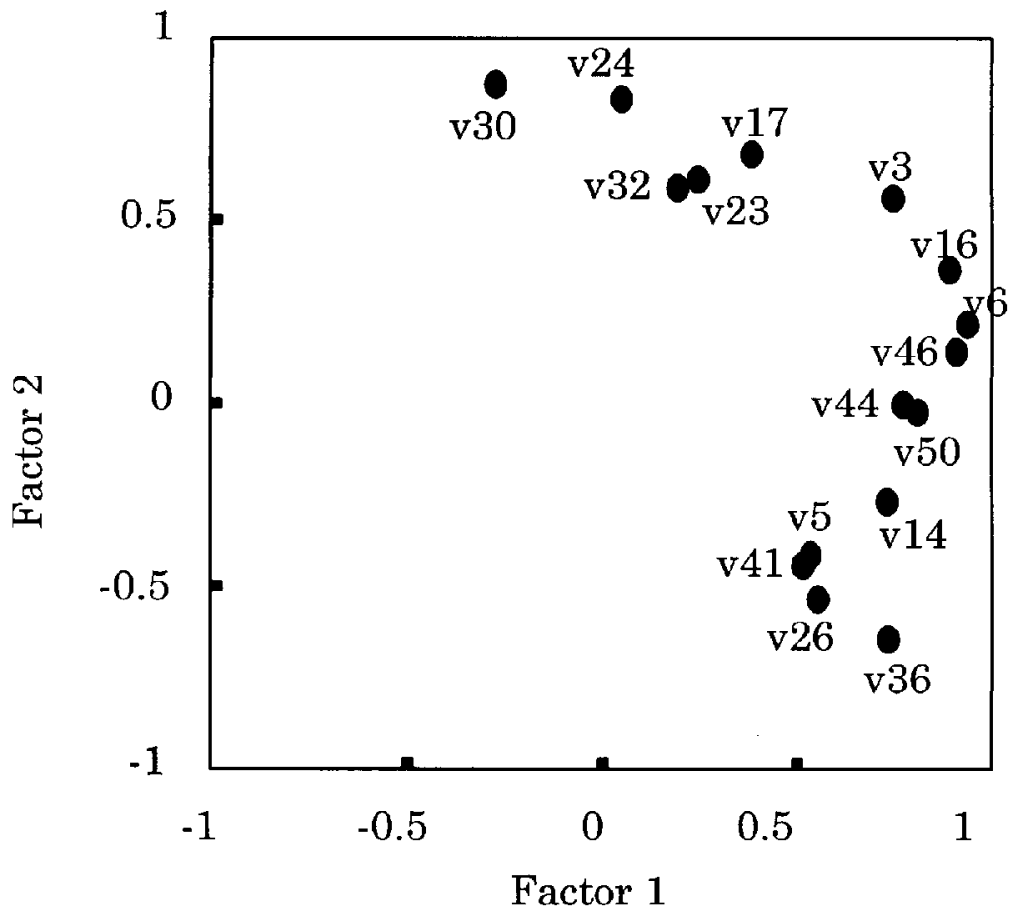

Figure 11.

Factor loadings (O vapor phase components).

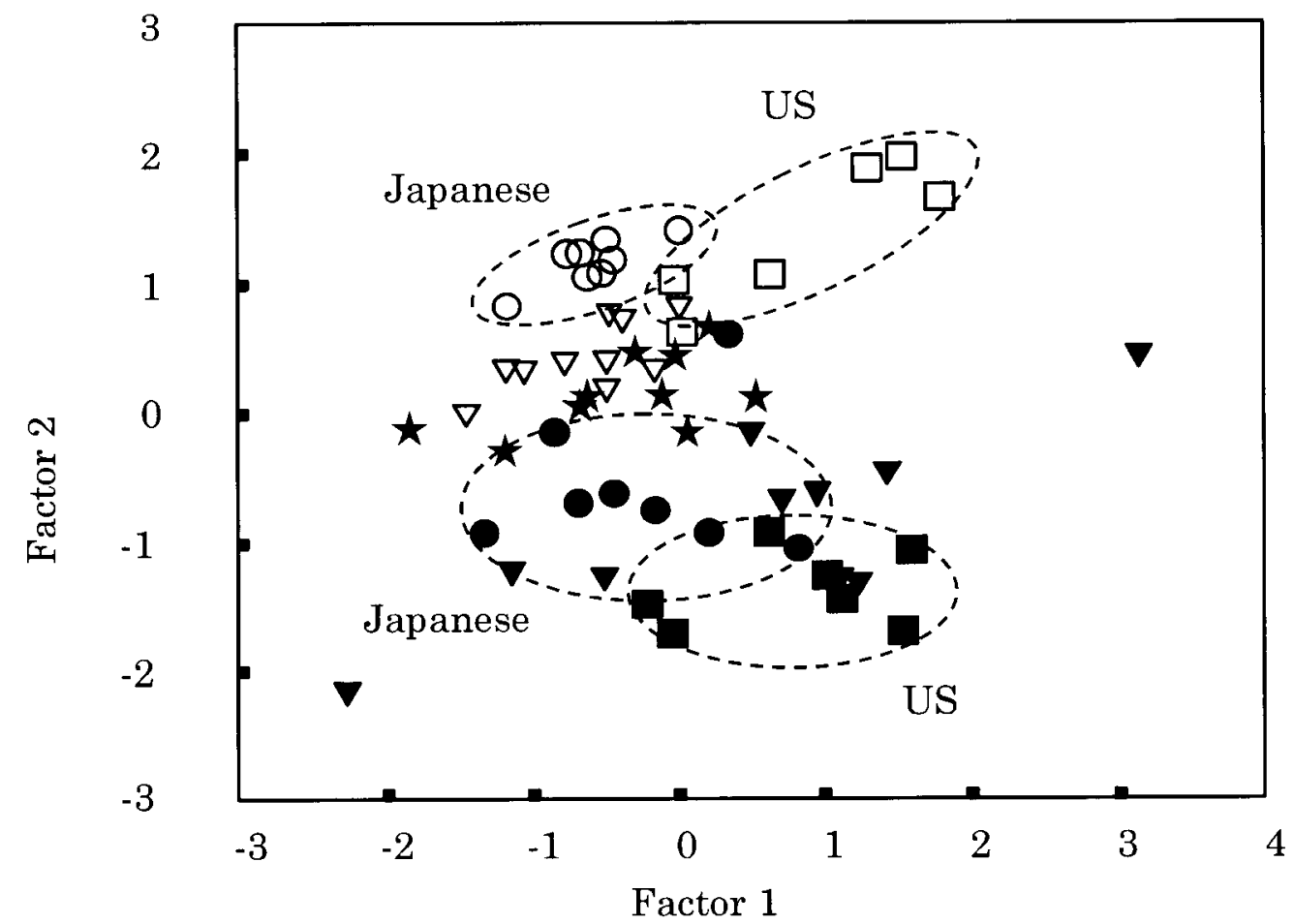

Figure 12.

Principal component scores (vapor phase components).

( $\star$ : Oriental; $\square$ : flue-cured USA; $\bigcirc$ : flue-cured Japan; $\nabla$ : flue-cured other countries; $\square$ : Burley USA; $\bigcirc$ : Burley Japan; $\nabla$ : Burley other countries)

principal component scores, the combination of the first and second principal components successfully identified the variety of total tobacco leaves more clearly than that of vapor phase components. As far as flue-cured tobacco 


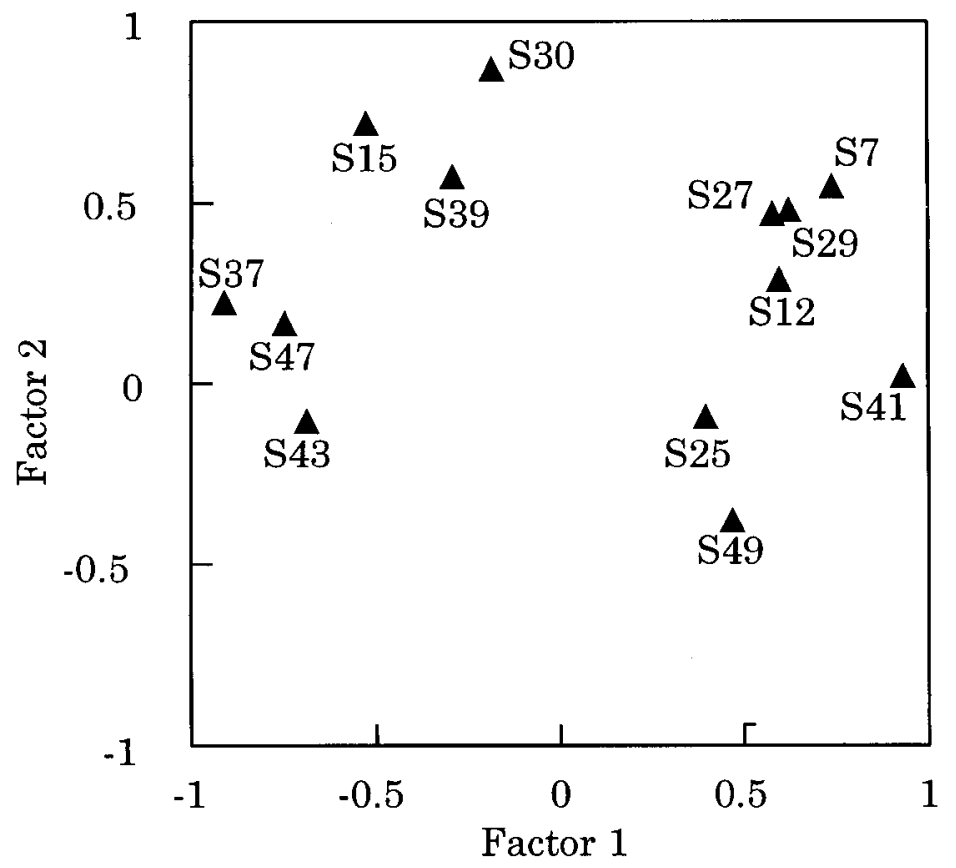

Figure 13.

Factor loadings ( $\boldsymbol{\Delta}$ : semivolatile components).

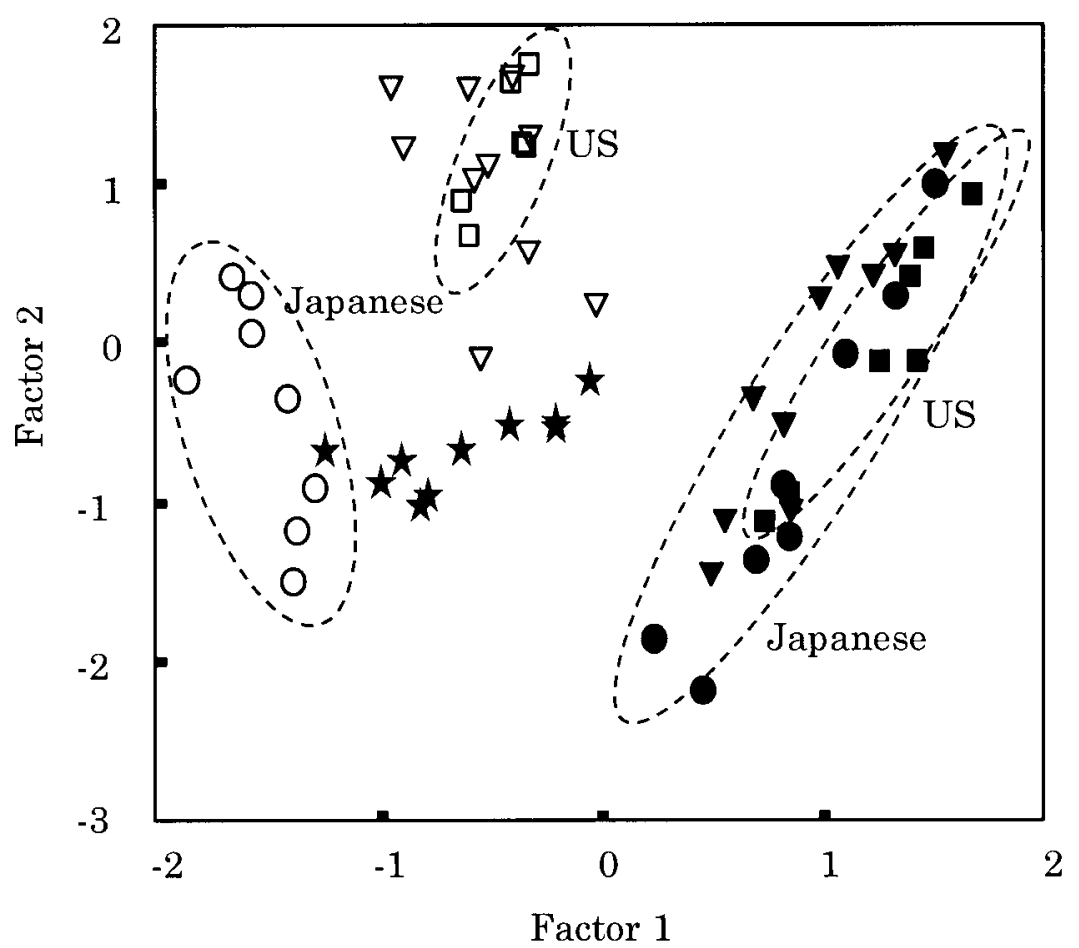

Figure 14.

Principal component scores (semivolatile components).

( $\star$ : Oriental; $\square$ : flue-cured USA; $\bigcirc$ : flue-cured Japan; $\nabla$ : flue-cured other countries; $\square$ : Burley USA; $\bigcirc$ : Burley Japan; $\nabla$ : Burley other countries)

is concerned, semivolatile component data successfully divided the plots into two distinctive groups each 
representing different country of origin more clearly than the vapor phase component data. It seems that the same data did not have sufficient information to classify Burley tobacco by county of origin. On the chart of factor loadings, the scatter plots might be divided into three groups: (1) oxygen-containing components, which seem to be derived from sugar pyrolysates; (2) phenols; and (3) nitrogen-containing components. The proportions of oxygen and nitrogen-containing components differentiate flue-cured and Burley tobacco. It seems that the Japanese flue-cured tobacco contains more oxygen-containing components and US flue-cured contains morephenols and acetic acid.

Principal component analysis using both vapor phase and semivolatile component data

The combined vapor phase and semivolatile component data were analyzed using PCA (Table 8, Figures 15 and 16). In the chart of principal component scores, the combination of the first and second principal components

Table 8.

PCA of combined data.

\begin{tabular}{l|c|c|c}
\hline \multicolumn{1}{c}{ Factor } & Eigenvalue & Proportion & Cumulative proportion \\
\hline 1 & 9.92 & 0.342 & 0.342 \\
2 & 6.95 & 0.240 & 0.582 \\
3 & 3.53 & 0.122 & 0.704 \\
4 & 2.02 & 0.070 & 0.774 \\
5 & 1.87 & 0.064 & 0.838 \\
6 & 1.37 & 0.047 & 0.885 \\
\hline
\end{tabular}

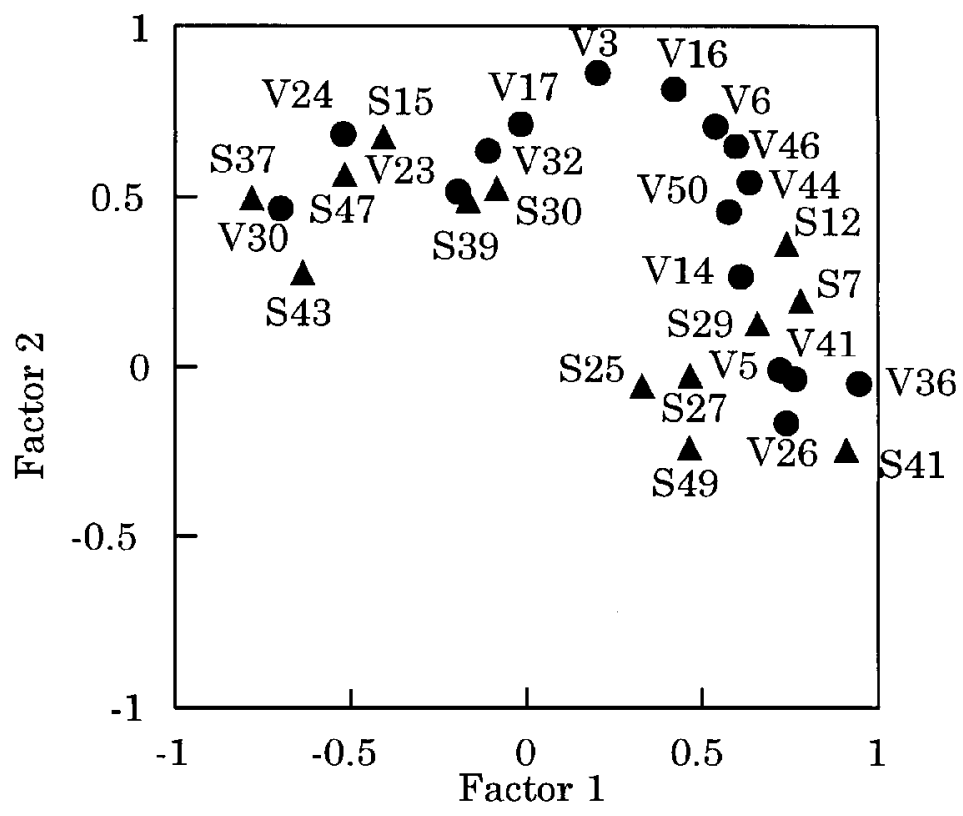

Figure 15.

Factor loadings. ( $\bigcirc$ : vapor phase components; $\nabla$ : semivolatile components). 


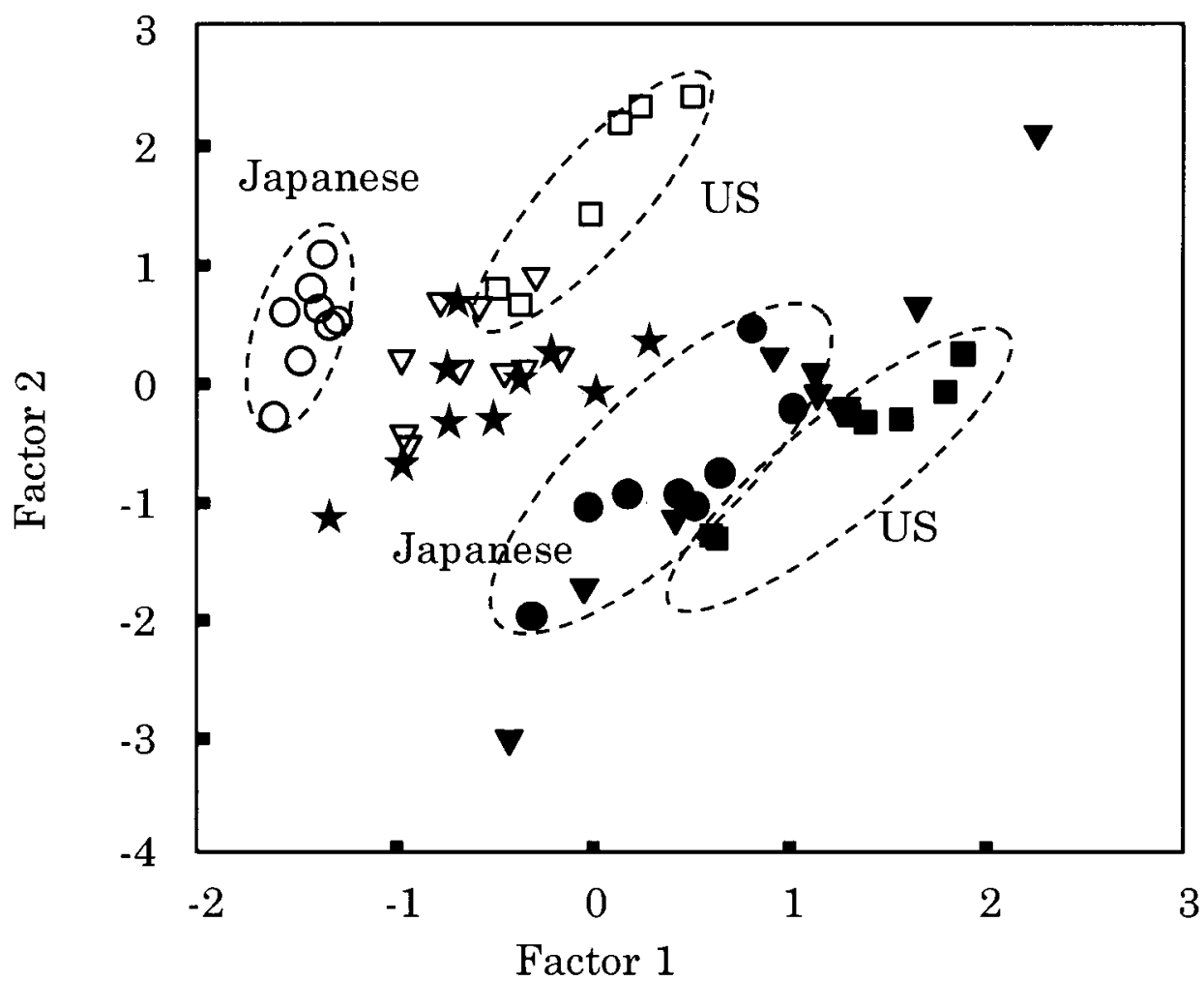

Figure 16.

Principal component scores (vapor phase and semivolatile components).

( $\star$ : Oriental; $\square$ : flue-cured USA; $\bigcirc$ : flue-cured Japan; $\nabla$ : flue-cured other countries; $\square$ : Burley USA; $\bigcirc$ : Burley Japan; $\nabla$ : Burley other countries)

identified the varieties and counties of origin of total tobacco leaves most clearly of all three PCA approaches. On the chart of factor loadings, scatter plots are also divided into three groups of oxygen-containing components, hydrocarbons and nitrogen-containing components. In the chart of principal component scores, the distribution of plots for each group such as Japanese fluecured was elliptic. The expanded distribution of plots for each group may be attributable to the presence of vapor phase components such as hydrocarbons.

\section{DISCUSSION}

\section{Usefulness of vapor phase component analysis}

The analytical method discussed here enables simple and precise determination of vapor phase components. The data from this analysis may be used to classify tobacco leaves. Although the vapor phase component data alone fail to provide sufficient information to clearly classify tobacco leaves by variety and by country of origin, when they are combined with semivolatile component data, more clear-cut classification is possible. The combined data also provide other useful information such as stalk positions. Furthermore, the data may be used to determine how irritable a particular tobacco leaf or cigarette is because some of vapor phase components are irritants. The multivariate analysis used in this study will also help to trace the precursors of vapor phase components the procedure for which has been highly complex.

\section{Qualitative differences between vapor phase and semivolatile component data}

While the vapor phase component data successfully identified the variety of total tobacco leaves, as far as countries of origin are concerned, the distribution of the plots did not separate into distinctive groups and even partially overlapped for both flue-cured and Burley tobacco. On the other hand, semivolatile component data successfully identified the variety of total tobacco leaves more clearly. Although semivolatile component data provide more information about flue-cured tobacco leaves than those on vapor phase do, the plots for US Burley tobacco were completely contained in the plot area for Japanese Burley. From the fact that the combined data clearly characterized Burley tobacco, vapor phase components seem to have useful information about Burley tobacco. 


\section{REFERENCES}

1. M.F. Dube and C.R. Green: Method of collection of smoke for analytical purposes; Recent Adv. Tob. Sci. 8 (1982) 42-102.

2. Y. Alarie: Sensory irritation by airborne chemicals; Crit. Rev. Toxicol. 2 (1973) 299-363.

3. W.W. Weeks: Chemistry of tobacco constituents influencing flavor and aroma; Recent Adv. Tob. Sci. 11 (1985) 175-200.

4. K. Izawa, H. Takahashi, T. Sasa, Y. Sone: New instrument for rapid analysis of tobacco smoke; $45^{\text {th }}$ Tobacco Science Research Conference, Program Booklet and Abstracts, Vol. 45, No. 46, 1991, 38.

5. A.H. Laurene, L.A. Lyerly and G.W. Young: Direct vapor chromatographic determination of acetaldehyde, acrolein and acetone in cigarette smoke; Tob. Sci. 8 (1964) 150-153.

6. E.L. White, A. Sequeria and C.O. Brooks: Ultrasensitive method for the direct determination of vinyl chloride in fresh mainstream vapor-phase cigarette smoke; $51^{\text {st }}$ Tobacco Science Research Conference, Program Booklet and Abstracts, Vol. 51, No. 50, 1997, p 55.

7. C.C. Morrison, D.E. Wingate and K.A. Beard: The effects of cigarette design modifications on selected mainstream vapor phase smoke constituent yield; $49^{\text {th }}$ Tobacco Science Research Conference, Program Booklet and Abstracts, Vol. 49, No. 44, 1994, p 44.

8. G.D. Byrd, K.W. Fowler, R.D. Hicks, M.E. Lovette and M.F. Borgerding: Isotope dilution gas chromatography-mass spectrometry in the determination of benzene, toluene, styrene and acrylonitrile in mainstream cigarette smoke; J. Chromatogr. 503 (1990) 359-368.

9. A.D. Horton and M.R. Guerin: Determination of acetaldehydes and acrolein in the gas phase of cigarette smoke using cryothermal gas chromatography; Tob. Sci. 18 (1974) 19-22.

10. J.R. Newsome, V. Norman and C.H. Keith: Vapor phase analysis of tobacco smoke; Tob. Sci. 9 (1965) 102-110.

11. H. Elmenhorst and R. Tschesche: Eine neue Kältefalle zur Gewinnung großer Mengen von Tabakrauchkondensat; Beitr. Tabakforsch. 3 (1965) 101-107.

12. R.M. Irby and E.S. Harlow: Cigarette smoke I. Determination of certain vapor constituents; Tob. Sci. 3 (1959) 52-56.

13. D.A. Lewis, I. Colbeck and D.C. Mariner: Diffusion denuder method for sampling vapor-phase nicotine in mainstream tobacco smoke; Anal. Chem. 66 (1994) 3525-3527.
14. G. MacLeod and J.M. Ames: Comparative assessment of the artifact background on thermal desorption of Tenax GC and Tenax TA; J. Chromatogr. 355 (1986) 393-398.

15. A.J. Nunez, L.F. Gonzalez and J. Janak: Pre-concentration of headspace volatiles for trace organic analysis by gas chromatography; J. Chromatogr. 300 (1984) 127-162.

16. C.E. Higgins, W.H. Griest and G. Olerich: Application of Tenax trapping to analysis of gas phase organic compounds in ultra-low tar cigarette smoke; J. Assoc. Off. Anal. Chem. 66 (1983) 1074-1083.

17. C.H. Sloan, J.S. Lewis and G.P. Morie: Computerization of the gas-phase analysis of cigarette smoke; Tob. Sci. 21 (1977) 57.

18. L.A. Gundel, V.C. Lee, K.R.R. Mahanama, R.K. Stevens and J.M. Daisey: Direct determination of the phase distributions of semi-volatile polycyclic aromatic hydrocarbons using annular denuders; Atmos. Environ. 29 (1995) 1719-1733.

19. N. Higashi, M. Chida, T. Sasa and S. Suhara: Tobacco vapor-phase measurement methodology and multivariate analysis using vapor-phase and semivolatile components; $50^{\text {th }}$ Tobacco Science Research Conference, Program Booklet and Abstracts, Vol. 50, No. 67, 1996, pp 60-61.

20. F. Omori, M Chida, Y. Sone and S. Suhara: Development of a way of introducing an internal standard for tobacco vapor phase measurement; $51^{\text {st }}$ Tobacco Science Research Conference, Program Booklet and Abstracts, Vol. 51, No. 53, 1997, pp 57-58.

21. Standard method and procedure for TIOJ related to tar and nicotine measurement; Notification of the ministry of finance.

22. Y. Shinozaki, K. Tobita, S. Suhara and Y. Tonoshige: Classification of tobacco leaves with their dichloromethane extracts; $48^{\text {th }}$ Tobacco Science Research Conference, Program Booklet and Abstracts, Vol. 48, No. 11, 1994, p 29.

23. M. Chida, K. Tobita, Y. Shinozaki and S. Suhara: A rapid method of extraction of the volatile components of tobacco leaves with the HP-prepstation tobacco leaf classification by multivariate analysis; $49^{\text {th }}$ Tobacco Science Research Conference, Program Booklet and Abstracts, Vol. 49, No. 33, 1995, p 37.

Address for correspondence:

Tobacco Science Research Laboratory

Japan Tobacco Inc.

6-2 Umegaoka, Aoba-ku, Yokohama, Kanagawa, 227-8512

Japan 